Jane Cristina Duarte dos Santos

\title{
TU ou VOCÊ?: uma questão de identidade cultural
}

\section{DISSERTAÇÃO DE MESTRADO}

\author{
DEPARTAMENTO DE LETRAS \\ Programa de Pós-Graduação em Letras \\ Estudos da Linguagem
}

Rio de Janeiro

Fevereiro de 2003 